\title{
Paenibacillus siamensis sp. nov., Paenibacillus septentrionalis sp. nov. and Paenibacillus montaniterrae sp. nov., xylanase-producing bacteria from Thai soils
}

Correspondence Ancharida Akaracharanya sanchari@chula.ac.th

\author{
Saowapar Khianngam, ${ }^{1}$ Somboon Tanasupawat, ${ }^{2}$ Jung-Sook Lee, ${ }^{3}$ \\ Keun Chul Lee ${ }^{3}$ and Ancharida Akaracharanya ${ }^{1}$ \\ ${ }^{1}$ Department of Microbiology, Faculty of Science, Chulalongkorn University, Bangkok 10330, \\ Thailand \\ ${ }^{2}$ Department of Microbiology, Faculty of Pharmaceutical Sciences, Chulalongkorn University, \\ Bangkok 10330, Thailand \\ ${ }^{3}$ Korean Collection for Type Cultures, Biological Resource Center, Korea Research Institute of \\ Bioscience and Biotechnology (KRIBB), Yusong, Daejeon 305-806, Republic of Korea
}

\begin{abstract}
Three strains of xylanase-producing bacteria, $\mathrm{S} 5-3^{\top}, \mathrm{X} 13-1^{\top}$ and $\mathrm{MXC2}-2^{\top}$, isolated from soils in Thailand, were characterized taxonomically based on their phenotypic and chemotaxonomic characteristics and 16S rRNA gene sequence comparisons. They were Gram-positive, facultatively anaerobic, spore-forming, rod-shaped bacteria. They contained meso-diaminopimelic acid in the cell-wall peptidoglycan. The DNA $G+C$ contents were respectively $45.8,47.3$ and $48.8 \mathrm{~mol} \%$. The predominant isoprenoid quinone was MK-7, and anteiso- $\mathrm{C}_{15: 0}$ and $\mathrm{C}_{16 \text { :o }}$ were the dominant cellular fatty acids. Phylogenetic analyses based on $16 \mathrm{~S}$ rRNA gene sequence comparison showed that they were affiliated to the genus Paenibacillus. Strains S5-3 $3^{\top}, X_{13}{ }^{\top}{ }^{\top}$ and MXC2-2 ${ }^{\top}$ were closely related to Paenibacillus granivorans $\mathrm{A}^{3} \mathrm{O}^{\top}$ and Paenibacillus agaridevorans DSM $1355^{\top}$ (94.7-98.6\% 16S rRNA gene sequence similarity). The similarity between the three novel strains ranged from 96.3 to $98.4 \%$. DNA-DNA relatedness, DNA G +C contents and some phenotypic characteristics could clearly distinguish the strains from each other and from related Paenibacillus species. Therefore, strains $\mathrm{S} 5-3^{\top}, \mathrm{X} 13-1^{\top}$ and MXC2-2 ${ }^{\top}$ represent novel species of the genus Paenibacillus, for which the names Paenibacillus siamensis sp. nov. (type strain S5-3 ${ }^{\top}=$ KCTC $13038^{\top}=$ PCU $279^{\top}=$ TISTR $1831^{\top}$ ), Paenibacillus septentrionalis sp. nov. (type strain X13-1 ${ }^{\top}=\mathrm{KCTC} 13039^{\top}=\mathrm{PCU} 280^{\top}=\mathrm{TISTR} 1830^{\top}$ ) and Paenibacillus montaniterrae sp. nov. (type strain MXC2-2 ${ }^{\top}=$ KCTC $13036^{\top}=\mathrm{PCU} 281^{\top}=$ TISTR $\left.1836^{\top}\right)$ are proposed.
\end{abstract}

Representatives of the genus Bacillus were first described as a group of micro-organisms that were characterized by endospore formation; the genus has subsequently been divided into a number of genera that belong to several families. This was the case for the genus Paenibacillus, which was proposed by Ash et al. (1993, 1994) and belongs to the family 'Paenibacillaceae'. Some of these bacteria excrete diverse assortments of extracellular polysaccharide-

Abbreviations: DAP, diaminopimelic acid; NJ, neighbour-joining.

The GenBank/EMBL/DDBJ accession numbers for the $16 \mathrm{~S}$ rRNA gene sequences of strains $\mathrm{S} 5-3^{\top}, \mathrm{MXC2}-2^{\top}$ and $\times 13-1^{\top}$ are AB295645AB295647, respectively.

Extended 16S rRNA gene sequence-based neighbour-joining and maximum-parsimony trees are available as supplementary material with the online version of this paper. hydrolysing enzymes, including xylanases (Zamost et al., 1991; Morales et al., 1995; Hespell, 1996; Aÿ et al., 1998; Nielsen \& Sorensen, 1997; Lee et al., 2000). Strains of Paenibacillus barcinonensis, P. favisporus, P. phyllosphaerae, P. xylanilyticus, $P$. cellulosilyticus, $P$. panacisoli and $P$. soli have been reported to degrade xylan (Rivas et al., 2005a, b, 2006; Sánchez et al., 2005; Velázquez et al., 2004; Ten et al., 2006; Park et al., 2007). In this paper, we describe novel xylanase-producing bacteria isolated from Thai soils based on their phenotypic and chemotaxonomic characteristics and $16 \mathrm{~S}$ rRNA gene sequence comparisons.

Three strains of xylanase-producing bacteria were isolated from soil samples collected from Muang and Viengsa districts in Nan province, in the northern part of Thailand, by the spread plate method on XC agar medium and 
incubation at $40{ }^{\circ} \mathrm{C}$ for 2 days. The $\mathrm{XC}$ medium contained 10 g oat-spelt xylan (Sigma), 5 g peptone (Difco), 1 g yeast extract (Difco), $4 \mathrm{~g} \mathrm{~K}_{2} \mathrm{HPO}_{4}, 1 \mathrm{~g} \mathrm{MgSO} 4.7 \mathrm{H}_{2} \mathrm{O}, 0.2 \mathrm{~g} \mathrm{KCl}$, $0.02 \mathrm{~g} \mathrm{FeSO}_{4} \cdot 7 \mathrm{H}_{2} \mathrm{O}$ and $1000 \mathrm{ml}$ distilled water and was adjusted to $\mathrm{pH}$ 7.0. The capacity of the cultures to produce xylanase was detected as described by Teather \& Wood (1982). Colonies grown on C agar medium, i.e. XC medium with the oat-spelt xylan omitted, were examined for their cell shape and colonial appearance, spore formation and pigmentation after incubation at $37{ }^{\circ} \mathrm{C}$ for 2 days. Motility was observed by phase-contrast microscopy. Catalase and oxidase activities, hydrolysis of $\mathrm{L}$ arginine, aesculin, casein, gelatin, starch and tyrosine, methyl red and Voges-Proskauer reactions, DNase activity, indole production, nitrate reduction, Simmons' citrate test, growth on triple-sugar iron (TSI) agar, dihydroxyacetone production from glycerol, urease activity and acid production from carbohydrates were determined as described by Barrow \& Feltham (1993). Additional biochemical characteristics were recorded after 2 days incubation in API 50 CHB strips. Growth under anaerobic conditions on agar plates was investigated using a Gaspak (BBL) anaerobic jar. Growth at $\mathrm{pH} 5,6,7,8$ and 9, in 3 and $5 \% \mathrm{NaCl}$ and at $10,15,20,30,37,45,50,55$ and $60{ }^{\circ} \mathrm{C}$ was tested by using $\mathrm{C}$ agar medium. All other tests were carried out by using $\mathrm{C}$ medium as a basal component and by incubating the cultures at $37{ }^{\circ} \mathrm{C}$. Diaminopimelic acid in the cell wall and isoprenoid quinone were determined as described by Komagata \& Suzuki (1987).
DNA was prepared by the method of Saito \& Miura (1963) DNA base composition was determined by reversed-phase HPLC (Tamaoka \& Komagata, 1984). The 16S rRNA genes of the strains were amplified and PCR products were purified and sequenced as described previously (Tanasupawat et al., 2004). The sequences determined (1464-1504 bases) were aligned with selected sequences obtained from the GenBank/EMBL/DDBJ databases by employing CLUSTAL_X version 1.83 (Thompson et al., 1997). Phylogenetic trees were reconstructed by using the neighbour-joining (NJ) method (Saitou \& Nei, 1987) and the maximum-parsimony method in the MEGA 4 software version 4 (Tamura et al., 2007). Confidence values of branches of the phylogenetic trees were determined using bootstrap analyses (Felsenstein, 1985) based on 1000 resamplings.

Strain $55-3^{\mathrm{T}}, \mathrm{X} 13-1^{\mathrm{T}}$ and $\mathrm{MXC2}-2^{\mathrm{T}}$ are Gram-positive, facultatively anaerobic, motile, rod-shaped bacteria. Central or subterminal ellipsoidal endospores are observed in swollen sporangia. Colonies of strain $\mathrm{S} 5-3^{\mathrm{T}}$ are white, circular or oval, flat, undulate and opaque $(0.05-2.5 \mathrm{~mm}$ in diameter), whereas colonies of strains X13- $1^{\mathrm{T}}$ and MXC2$2^{\mathrm{T}}$ are white, circular, convex, entire and translucent $(0.02-$ $1.0 \mathrm{~mm}$ in diameter) on $\mathrm{C}$ agar plates. The strains were characterized based on their morphological, cultural, physiological and biochemical properties including chemotaxonomic characteristics. Results are listed in the species descriptions and Tables 1 and 2. In the 16S rRNA gene sequence-based phylogenetic tree reconstructed

Table 1. Differential characteristics of the novel strains and $P$. agaridevorans KCTC $3849^{\top}$

Strains: 1 , S5-3 ${ }^{\mathrm{T}} ; 2$, X13-1 ${ }^{\mathrm{T}} ; 3$, MXC2-2 ${ }^{\mathrm{T}} ; 4$, P. agaridevorans KCTC $3849^{\mathrm{T}}$ (data from this study and from Uetanabaro et al., 2003). +, Positive; $\mathrm{W}$, weakly positive; - , negative.

\begin{tabular}{|c|c|c|c|c|}
\hline Characteristic & 1 & 2 & 3 & 4 \\
\hline Oxidase & + & - & - & - \\
\hline Voges-Proskauer reaction & + & + & + & - \\
\hline Growth in $5 \% \mathrm{NaCl}$ & + & + & + & - \\
\hline Growth at $50{ }^{\circ} \mathrm{C}$ & + & - & + & - \\
\hline L-Arabinose, L-rhamnose, D-xylose & + & - & + & - \\
\hline D-Fructose, D-mannose & - & - & $\mathrm{w}$ & - \\
\hline D-Galactose, D-lactose & + & - & + & + \\
\hline Glycerol & - & - & $\mathrm{w}$ & - \\
\hline Glycogen, starch & + & + & + & - \\
\hline Methyl $\alpha$-D-glucoside & + & - & - & + \\
\hline Methyl $\beta$-xyloside & + & - & + & + \\
\hline D-Ribose & + & - & $\mathrm{W}$ & - \\
\hline DNA G $+\mathrm{C}$ content $(\mathrm{mol} \%)$ & 45.8 & 47.3 & 48.8 & 51 \\
\hline
\end{tabular}


Table 2. Cellular fatty acid profiles of the novel strains and $P$. agaridevorans KCTC $3849^{\top}$

Strains: $1, \mathrm{~S} 5-3^{\mathrm{T}} ; 2, \mathrm{X} 13-1^{\mathrm{T}} ; 3, \mathrm{MXC} 2-2^{\mathrm{T}} ; 4$, P. agaridevorans KCTC $3849^{\mathrm{T}}$. Data were determined in this study. Values are percentages of total fatty acids; ND, not detected.

\begin{tabular}{|c|c|c|c|c|}
\hline Fatty acid & 1 & 2 & 3 & 4 \\
\hline \multicolumn{5}{|c|}{ Saturated fatty acids } \\
\hline $\mathrm{C}_{12: 0}$ & $\mathrm{ND}$ & 0.1 & 0.1 & 0.1 \\
\hline $\mathrm{C}_{14: 0}$ & 1.2 & 1.6 & 2.1 & 0.9 \\
\hline $\mathrm{C}_{15: 0}$ & 3.3 & 0.7 & 2.1 & 1.2 \\
\hline $\mathrm{C}_{16: 0}$ & 15.6 & 19.3 & 19.8 & 13.1 \\
\hline $\mathrm{C}_{16: 0} \mathrm{~N}$-alcohol & $\mathrm{ND}$ & $\mathrm{ND}$ & 0.2 & ND \\
\hline $\mathrm{C}_{16: 0} \omega 7 c$ alcohol & $\mathrm{ND}$ & ND & 0.8 & 0.1 \\
\hline $\mathrm{C}_{17: 0}$ & 1.4 & 0.3 & 0.9 & 0.5 \\
\hline $\mathrm{C}_{18: 0}$ & 0.4 & 0.3 & 0.6 & 1.7 \\
\hline \multicolumn{5}{|c|}{ Unsaturated fatty acids } \\
\hline $\mathrm{C}_{14: 1} \omega 5$ & $\mathrm{ND}$ & $\mathrm{ND}$ & 0.1 & 0.1 \\
\hline $\mathrm{C}_{16: 1} \omega 11 c$ & 1.6 & 1.7 & 5.6 & 0.2 \\
\hline $\mathrm{C}_{18: 1} \omega 9 c$ & ND & ND & 0.2 & 0.6 \\
\hline $\mathrm{C}_{18: 3} \omega 6 c(6,9,12)$ & $\mathrm{ND}$ & $\mathrm{ND}$ & 0.1 & ND \\
\hline \multicolumn{5}{|c|}{ Branched fatty acids } \\
\hline anteiso- $\mathrm{C}_{11: 0}$ & $\mathrm{ND}$ & 0.1 & 0.1 & ND \\
\hline iso- $\mathrm{C}_{14: 0}$ & 1.8 & 1.8 & 2.2 & 2.7 \\
\hline iso- $\mathrm{C}_{15: 0}$ & 2.8 & 3.9 & 3.8 & 5.4 \\
\hline anteiso- $\mathrm{C}_{15: 0}$ & 41.3 & 36.2 & 34.7 & 42.4 \\
\hline iso- $\mathrm{C}_{16: 0}$ & 10.9 & 10.1 & 12.1 & 17.7 \\
\hline iso- $\mathrm{C}_{17: 0}$ & 6.4 & 9.0 & 5.7 & 5.6 \\
\hline anteiso- $\mathrm{C}_{17: 0}$ & 12.9 & 14.4 & 7.3 & 6.5 \\
\hline iso- $\mathrm{C}_{17: 1} \omega 10 c$ & ND & ND & 0.5 & ND \\
\hline iso- $\mathrm{C}_{18: 0}$ & 0.4 & 0.3 & 0.3 & 0.2 \\
\hline
\end{tabular}

according to the NJ method, strains $\mathrm{S} 5-3^{\mathrm{T}}, \mathrm{X} 13-1^{\mathrm{T}}$ and MXC2-2 ${ }^{\mathrm{T}}$ were grouped in a monophyletic cluster within the genus Paenibacillus (Fig. 1). Trees constructed by the NJ and maximum-parsimony methods including strains $\mathrm{S} 5-3^{\mathrm{T}}$, X13-1 $1^{\mathrm{T}}$ and $\mathrm{MXC2}-2^{\mathrm{T}}$ and representatives of all Paenibacillus species are shown as Supplementary Figs S1 and S2, available in IJSEM Online. Strains S5-3 ${ }^{\mathrm{T}}, \mathrm{X} 13-1^{\mathrm{T}}$ and MXC2- $2^{\mathrm{T}}$ were closely related to each other $(96.3-98.4 \%$ 16S rRNA gene sequence similarity) and to Paenibacillus granivorans $\mathrm{A} 30^{\mathrm{T}}$ (97.5, 96.9 and $98.6 \%$ similarity, respectively) and Paenibacillus agaridevorans DSM $1355^{\mathrm{T}}$ (94.7, 95.6 and $96.0 \%$ ). In addition, they were related to Paenibacillus agarexedens DSM $1327^{\mathrm{T}}$, P. alkaliterrae KSL$134^{\mathrm{T}}$, P. curdlanolyticus DSM $10247^{\mathrm{T}}$ and P. xinjiangensis $\mathrm{B} 538^{\mathrm{T}}$ with $92.9-95.4 \%$ sequence similarity.

The three strains contained meso-diaminopimelic acid (meso-DAP) as the diagnostic diamino acid in the cell-wall peptidoglycan and MK-7 as the major isoprenoid quinone. The three strains showed similar fatty acid profiles, but there were significant quantitative differences. Anteiso- $\mathrm{C}_{15: 0}$ $(34.7-41.3 \%)$ and $C_{16: 0}(15.6-19.8 \%)$ were the dominant cellular fatty acids. The percentages of the other fatty acids are listed in Table 2. Anteiso- $\mathrm{C}_{15: 0}, \mathrm{C}_{16: 1} \omega 11 \mathrm{c}$ and anteiso$\mathrm{C}_{17: 0}$ were detected in $\mathrm{S}_{5}-3^{\mathrm{T}}$ in significantly different amounts from MXC2-2 $2^{\mathrm{T}}$. In addition, $\mathrm{C}_{14: 1} \omega 5, \mathrm{C}_{16: 0}$

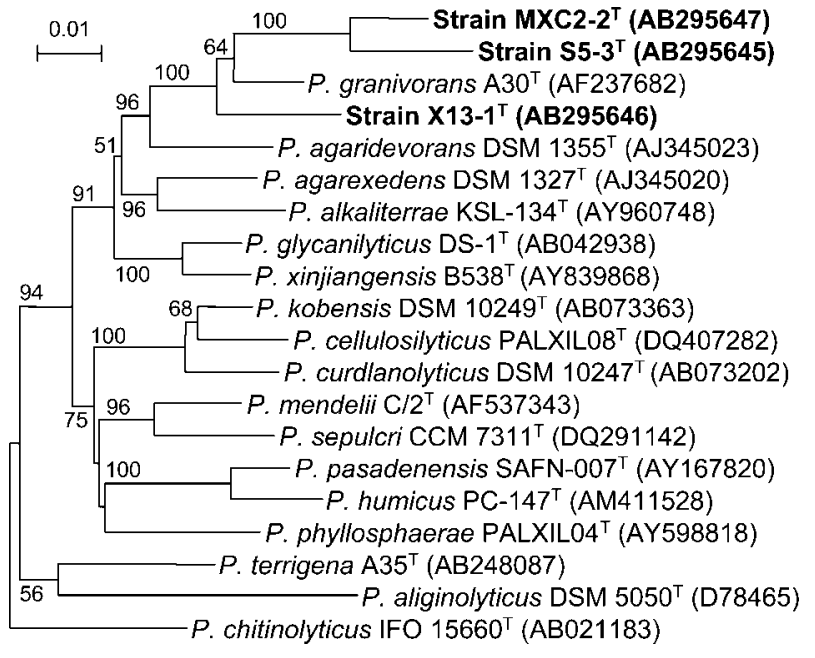

Fig. 1. NJ tree of $16 \mathrm{~S}$ rRNA gene sequences showing the phylogenetic relationships between strains $S 5-3^{\top}, X 13-1^{\top}$ and MXC2-2 ${ }^{\top}$ and some Paenibacillus species. Bootstrap percentages above $51 \%$ based on 1000 replications are shown. Bar, 0.01 substitutions per nucleotide position. Extended NJ and maximum-parsimony trees including representatives of all Paenibacillus species are available as Supplementary Figs S1 and S2.

$\mathrm{N}$-alcohol, $\mathrm{C}_{16: 0} \omega 7 c$ alcohol, iso- $\mathrm{C}_{17: 1} \omega 10 c, \mathrm{C}_{18: 1} \omega 9 c$ and $\mathrm{C}_{18: 3 \omega 6 c}(6,9,12)$, detected in strain MXC2-2 ${ }^{\mathrm{T}}$, were not detectable in $55-3^{\mathrm{T}}$ or X13-1 ${ }^{\mathrm{T}}$ (Table 2).

The three novel strains could be differentiated from each other and from $P$. granivorans $\mathrm{A} 30^{\mathrm{T}}$ and $P$. agaridevorans KCTC $3849^{\mathrm{T}}$ by their catalase and oxidase production, nitrate reduction, Voges-Proskauer reaction, growth in $5 \% \mathrm{NaCl}$ and at $50{ }^{\circ} \mathrm{C}$, acid production from carbohydrates and DNA G $+\mathrm{C}$ contents, as shown in Table 1 and reported by Van der Maarel et al. (2000). DNA-DNA relatedness values among strains $\mathrm{S} 5-3^{\mathrm{T}}, \mathrm{X} 13-1^{\mathrm{T}}$ and MXC2$2^{\mathrm{T}}$ and $P$. agaridevorans KCTC $3849^{\mathrm{T}}$ were $2.2-18.5 \%$. We were unable to determine DNA-DNA hybridization results between $P$. granivorans $\mathrm{A} 30^{\mathrm{T}}$ and our strains in this study because $P$. granivorans $\mathrm{A} 30^{\mathrm{T}}$ was deposited in the CBS as a patent strain and was not available (Euzéby, 2008). Based on these results, these strains represent three novel species of the genus Paenibacillus (Shida et al., 1997; Van der Maarel et al., 2000; Uetanabaro et al., 2003; Yoon et al., 2005), for which the names Paenibacillus siamensis sp. nov., Paenibacillus septentrionalis sp. nov. and Paenibacillus montaniterrae sp. nov. are proposed.

\section{Description of Paenibacillus siamensis sp. nov.}

Paenibacillus siamensis (si.am.en'sis. N.L. masc. adj. siamensis pertaining to Siam, the old name of Thailand, where the type strain was isolated).

Cells are Gram-positive rods, $0.5-0.8 \times 3.0-12.0 \mu \mathrm{m}$. Central or subterminal ellipsoidal endospores are observed 
in swollen sporangia. Facultatively anaerobic. Grows at $\mathrm{pH} 7-9$, at $15-50{ }^{\circ} \mathrm{C}$, in 3 and $5 \% \mathrm{NaCl}$ and under anaerobic conditions; does not grow at $\mathrm{pH} 5-6,10{ }^{\circ} \mathrm{C}$ or $55-60{ }^{\circ} \mathrm{C}$. Positive for catalase, oxidase, the VogesProskauer reaction, urease and hydrolysis of aesculin, starch and Tween 80; negative for the methyl red test, DNase, indole production, growth on Simmons' citrate and TSI agar, nitrate reduction, dihydroxyacetone production and hydrolysis of L-arginine, casein, gelatin and L-tyrosine. Acid is produced from amygdalin, aesculin, Larabinose, cellobiose, D-galactose, gentiobiose, methyl $\alpha$-Dglucoside, glycogen, D-lactose, maltose, D-mannitol, melibiose, raffinose, L-rhamnose, D-ribose, salicin, starch, sucrose, trehalose, turanose, methyl $\beta$-xyloside and $\mathrm{D}$ xylose. No acid production from D-arabinose, D- or L-arabitol, D-adonitol, $\mathrm{N}$-acetylglucosamine, arbutin, dulcitol, erythritol, D-fructose, D- or L-fucose, gluconate, 2- or 5-ketogluconate, D-glucose, glycerol, inositol, inulin, Dlyxose, D-mannose, methyl $\alpha$-D-mannoside, melezitose, D-tagatose, L-sorbose, D-sorbitol, xylitol or L-xylose. The cell-wall diamino acid is meso-DAP. The major menaquinone is MK-7. The DNA G + C content of the type strain is $45.8 \mathrm{~mol} \%$. The predominant cellular fatty acids are anteiso- $\mathrm{C}_{15: 0}$ and $\mathrm{C}_{16: 0}$.

The type strain is $55-3^{\mathrm{T}}\left(=\right.$ KCTC $13038^{\mathrm{T}}=$ PCU $279^{\mathrm{T}}$ $=$ TISTR $1831^{\mathrm{T}}$ ).

\section{Description of Paenibacillus septentrionalis sp. nov.}

Paenibacillus septentrionalis (sep.ten'tri.o.na'lis. L. masc. adj. septentrionalis northern, referring to the isolation of the type strain from the northern province, Nan, Thailand).

Cells are Gram-positive rods, $0.5-0.8 \times 2.0-12 \mu \mathrm{m}$. Central or subterminal ellipsoidal endospores are observed in swollen sporangia. Facultatively anaerobic. Grows at $\mathrm{pH} 7$ 9 , at $15-45{ }^{\circ} \mathrm{C}$, in 3 and $5 \% \mathrm{NaCl}$ and under anaerobic conditions; does not grow at $\mathrm{pH} 5-6,10{ }^{\circ} \mathrm{C}$ or $50-60{ }^{\circ} \mathrm{C}$. Positive for catalase, the Voges-Proskauer reaction, urease and hydrolysis of aesculin, starch and Tween 80; negative for oxidase, the methyl red test, DNase, indole production, growth on Simmons' citrate and TSI agar, nitrate reduction, dihydroxyacetone production and hydrolysis of L-arginine, casein, gelatin and L-tyrosine. Acid production from aesculin, D-glucose, glycogen and starch. No acid production from adonitol, amygdalin, D- or L-arabinose, D- or L-arabitol, arbutin, cellobiose, dulcitol, erythritol, Dfructose, D- or L-fucose, D-galactose, gentiobiose, gluconate, 2 - or 5-ketogluconate, glycerol, methyl $\alpha$-D-glucoside, $\mathrm{N}$-acetylglucosamine, inositol, inulin, D-lactose, maltose, D-mannose, methyl $\alpha$-D-mannoside, D-mannitol, melezitose, melibiose, raffinose, L-rhamnose, D-ribose, D- or Lxylose, methyl $\beta$-D-xyloside, salicin, L-sorbose, D-sorbitol, sucrose, trehalose, xylitol, turanose, D-lyxose or D-tagatose. The cell-wall diamino acid is meso-DAP. The major menaquinone is MK-7. The DNA G $+\mathrm{C}$ content of the type strain is $47.3 \mathrm{~mol} \%$. The predominant cellular fatty acids are anteiso- $\mathrm{C}_{15: 0}$ and $\mathrm{C}_{16: 0}$.

The type strain is X13-1 $1^{\mathrm{T}}\left(=\right.$ KCTC $13039^{\mathrm{T}}=$ PCU $280^{\mathrm{T}}$ $=$ TISTR $1830^{\mathrm{T}}$ ).

\section{Description of Paenibacillus montaniterrae sp. nov.}

Paenibacillus montaniterrae (mon.ta'ni.ter'rae. L. adj. montanus of a mountain, L. n. terra soil; N.L. gen. n. montaniterrae of mountain soil, where the type strain was isolated).

Cells are Gram-positive rods, $0.5-0.8 \times 2-11 \mu \mathrm{m}$. Central or subterminal ellipsoidal endospores are observed in swollen sporangia. Facultatively anaerobic. Grows in 3 and $5 \% \mathrm{NaCl}$, at pH $7-9$ and at $15-50{ }^{\circ} \mathrm{C}$ and under anaerobic conditions; does not grow at pH $5-6,10{ }^{\circ} \mathrm{C}$ or $55-60{ }^{\circ} \mathrm{C}$. Positive for the Voges-Proskauer reaction, urease and hydrolysis of aesculin, starch and Tween 80; negative for catalase, oxidase, the methyl red test, DNase, indole production, growth on Simmons' citrate and TSI agar, nitrate reduction, dihydroxyacetone production and hydrolysis of L-arginine, casein, gelatin and L-tyrosine. Acid production from amygdalin, aesculin, L-arabinose, cellobiose, D-fructose, D-galactose, D-glucose, glycerol, glycogen, gentiobiose, inulin, D-lactose, maltose, D-mannitol, D-mannose, melibiose, methyl $\beta$-xyloside, raffinose, L-rhamnose, D-ribose, salicin, starch, sucrose, trehalose, turanose and D-xylose. No acid production from $\mathrm{N}$ acetylglucosamine, D-adonitol, arbutin, D-arabinose, D- or L-arabitol, erythritol, dulcitol, D- or L-fucose, gluconate, 2or 5-ketogluconate, inositol, melezitose, methyl $\alpha$-Dmannoside, D-lyxose, methyl $\alpha$-D-glucoside, D- or Lsorbitol, L-xylose, xylitol or D-tagatose. The cell-wall diamino acid is meso-DAP. The major menaquinone is MK-7. The DNA G+C content of the type strain is $48.8 \mathrm{~mol} \%$. The predominant cellular fatty acids are anteiso- $\mathrm{C}_{15: 0}$ and $\mathrm{C}_{16: 0}$.

The type strain is MXC2-2 $2^{\mathrm{T}}\left(=\mathrm{KCTC} 13036^{\mathrm{T}}=\mathrm{PCU} 281^{\mathrm{T}}\right.$ $=$ TISTR $1836^{\mathrm{T}}$ ).

\section{Acknowledgements}

This study was supported in part by a Government Research Grant, Chulalongkorn University (2005-2007), and a grant from the KRIBB Research Initiative Program.

\section{References}

Ash, C., Priest, F. G. \& Collins, M. D. (1993). Molecular identification of rRNA group 3 bacilli (Ash, Farrow, Wallbanks and Collins) using a PCR probe test. Antonie van Leeuwenhoek 64, 253-260.

Ash, C., Priest, F. G. \& Collins, M. D. (1994). Paenibacillus gen. nov. In Validation of the Publication of New Names and New Combinations Previously Effectively Published Outside the IJSB, List no. 51. Int J Syst Bacteriol 44, 852-853. 
Aÿ, J., Goetz, F., Borriss, R. \& Heinemann, U. (1998). Structure and function of the Bacillus hybrid enzyme GluXyn-1: native-like jellyroll fold preserved after insertion of autonomous globular domain. Proc Natl Acad Sci U S A 95, 6613-6618.

Barrow, G. I. \& Feltham, R. K. A. (1993). Cowan and Steel's Manual for the Identification of Medical Bacteria, 3rd edn. Cambridge: Cambridge University Press.

Euzéby, J. P. (2008). List of Prokaryotic Names with Standing in Nomenclature. Last full update 2 May 2008. http://www.bacterio. cict.fr/index.html

Felsenstein, J. (1985). Confidence limits on phylogenies: an approach using the bootstrap. Evolution 39, 783-791.

Hespell, R. B. (1996). Fermentation of xylan, corn fiber, or sugars to acetoin and butanediol by Bacillus polymyxa strains. Curr Microbiol 32, 291-296.

Komagata, K. \& Suzuki, K. (1987). Lipid and cell-wall analysis in bacterial systematics. Methods Microbiol 19, 161-207.

Lee, H. J., Shin, D. J., Cho, N. C., Kim, H. O., Shin, S. Y., Im, S. Y., Lee, H. B., Chum, S. B. \& Bai, S. (2000). Cloning, expression and nucleotide sequences of two xylanase genes from Paenibacillus sp. Biotechnol Lett 22, 387-392.

Morales, P., Madarro, A., Flors, A., Sendra, J. M. \& Pérez-González, J. A. (1995). Purification and characterization of a xylanase and an arabinofuranosidase from Bacillus polymyxa. Enzyme Microb Technol 17, 424-429.

Nielsen, P. \& Sorensen, J. (1997). Multi-target and medium in dependent fungal antagonisms by hydrolytic enzymes in Paenibacillus polymyxa and Bacillus pumilus strains from barley rhizosphere. FEMS Microbiol Ecol 22, 183-192.

Park, M. J., Kim, H. B., An, D. S., Yang, H. C., Oh, S. T., Chung, H. J. \& Yang, D. C. (2007). Paenibacillus soli sp. nov., a xylanolytic bacterium isolated from soil. Int J Syst Evol Microbiol 57, 146-150.

Rivas, R., Mateos, P. F., Martínez-Molina, E. \& Velázquez, E. (2005a). Paenibacillus xylanilyticus sp. nov., an airborne xylanolytic bacterium. Int J Syst Evol Microbiol 55, 405-408.

Rivas, R., Mateos, P. F., Martínez-Molina, E. \& Velázquez, E. (2005b). Paenibacillus phyllosphaerae sp. nov., a xylanolytic bacterium isolated from the phyllosphere of Phoenix dactylifera. Int J Syst Evol Microbiol 55, 743-746.

Rivas, R., Garcia-Fraile, P., Mateos, P. F., Martínez-Molina, E. \& Velázquez, E. (2006). Paenibacillus cellulosilyticus sp. nov., a cellulolytic and xylanolytic bacterium isolated from the bract phyllosphere of Phoenix dactylifera. Int J Syst Evol Microbiol 56, 2777-2781.

Saito, H. \& Miura, K. (1963). Preparation of transforming deoxyribonucleic acid by phenol treatment. Biochim Biophys Acta 72, 619-629.

Saitou, N. \& Nei, M. (1987). The neighbor-joining method: a new method for reconstructing phylogenetic trees. Mol Biol Evol 4, 406-425.
Sánchez, M. M., Fritze, D., Blanco, A., Spröer, C., Tindall, B. J., Schumann, P., Kroppenstedt, R. M., Diaz, P. \& Pastor, F. I. J. (2005). Paenibacillus barcinonensis sp. nov., a xylanase-producing bacterium isolated from a rice field in the Ebro River delta. Int J Syst Evol Microbiol 55, 935-939.

Shida, O., Takagi, H., Kadowaki, K., Nakamura, L. K. \& Komagata, K. (1997). Transfer of Bacillus alginolyticus, Bacillus chondroitinus, Bacillus curdlanolyticus, Bacillus glucanolyticus, Bacillus kobensis, and Bacillus thiaminolyticus to the genus Paenibacillus and emended description of the genus Paenibacillus. Int J Syst Bacteriol 47, 289-298.

Tamaoka, J. \& Komagata, K. (1984). Determination of DNA base composition by reversed-phase high-performance liquid chromatography. FEMS Microbiol Lett 25, 125-128.

Tamura, K., Dudley, J., Nei, M. \& Kumar, S. (2007). MEGA 4: molecular evolutionary genetics analysis (MEGA) software version 4.0. Mol Biol Evol 24, 1596-1599.

Tanasupawat, S., Thawai, C., Yukphan, P., Moonmangmee, D., Itoh, T., Adachi, O. \& Yamada, Y. (2004). Gluconobacter thailandicus sp. nov., an acetic acid bacterium in the $\alpha$-proteobacteria. J Gen Appl Microbiol 50, 159-167.

Teather, R. M. \& Wood, P. J. (1982). Use of Congo red polysaccharide interaction in enumeration of cellulolytic bacteria from bovine rumen. Appl Environ Microbiol 43, 777-780.

Ten, L. N., Baek, S. H., Im, W. T., Lee, M., Oh, H. W. \& Lee, S. T. (2006). Paenibacillus panacisoli sp. nov., a xylanolytic bacterium isolated from soil in a ginseng field in South Korea. Int J Syst Evol Microbiol 56, 2677-2681.

Thompson, J. D., Gibson, T. J., Plewniak, F., Jeanmougin, F. \& Higgins, D. G. (1997). The CLUSTAL_X windows interface: flexible strategies for multiple sequence alignment aided by quality analysis tools. Nucleic Acids Res 25, 4876-4882.

Uetanabaro, A. P., Wahrenburg, C., Hunger, W., Pukall, R., Spröer, C., Stackebrandt, E., de Canhos, V. P., Claus, D. \& Fritze, D. (2003). Paenibacillus agarexedens sp. nov., nom. rev., and Paenibacillus agaridevorans sp. nov. Int J Syst Evol Microbiol 53, 1051-1057.

Van der Maarel, M. J. E. C., Veen, A. \& Wijbenga, D. J. (2000). Paenibacillus granivorans sp. nov., a new Paenibacillus species which degrades native potato starch granules. Syst Appl Microbiol 23, 344348.

Velázquez, E., de Miguel, T., Poza, M., Rivas, R., Rosselló-Mora, R. \& Villa, T. G. (2004). Paenibacillus favisporus sp. nov., a xylanolytic bacterium isolated from cow faeces. Int J Syst Evol Microbiol 54, 59-64.

Yoon, J. H., Kang, S. J., Yeo, S. H. \& Oh, T. K. (2005). Paenibacillus alkaliterrae sp. nov., isolated from an alkaline soil in Korea. Int J Syst Evol Microbiol 55, 2339-2344.

Zamost, B. L., Nielson, H. K. \& Starnes, R. L. (1991). Thermostable enzymes for industrial applications. J Ind Microbiol 8, 71-82. 